Innovation of Vocational Technology Education

Available online at http://ejournal.upi.edu/index.php/invotec

\title{
N
}

invotec

\section{Application Model Learning Scaffolding on the Subject Lesson Vocational Competence Student}

\author{
Lucy Yosita, Anisa Samawati L \& Johar Maknun \\ Universitas Pendidikan Indonesia, Indonesia
}

ARTICLE INFO

Article history:

Received 09 Juni 2016

Received in revised form 12

July 2016

Accepted 26 July 2016

Available online 31 August 2016

Keywords:

Learning scaffolding

Vocational lesson

Motivation learning

Corresponding author:

lucyyosita@upi.edu
A B S TR A C T

The background of this study is about the lack result and motivation of student in the Building Technique Class. Meanwhile the aims to determine the difference between the learning outcomes as well as motivation of students whose learning application of the learning model scaffolding to students who are learning to apply conventional learning models. This study uses a true experimental research methods by using posttest only control group design with quantitative approach. The subjects were students of class X Building Design Technique SMKN 9 Garut totaling 40 subjects involving teacher's vocational competence. The research instrument is 5 essay tests to measure learning outcomes, 20 questionnaires to measure the motivation to learn and research documentation. Based on the analysis of research we concluded that: a) there is a difference between learning outcomes of students whose learning applying the learning model scaffolding with students who learning without applying the learning model scaffolding (conventional). This is indicated by the acquired Sig. amounting to 2.851>1.695 b) there is a difference between students' motivation is learning to apply learning models scaffolding with students whose learning without applying the learning model scaffolding (conventional). This is indicated by the acquired Sig. amounting to $2.851>1.685$.

\section{Introduction}

Education is a way to get information or knowledge one of which occurred in the school environment. In school education activity occurs during the learning process. Meanwhile, the learning process produces a direct interaction between teachers and students as learning activities. Reflection and learning activities demonstrated through the learning outcomes achieved by students and the motivation to learn what happened to the student. According to Shah (2004: 150), the ideal learning outcomes covering all domains psychologists is that change as a result of the experience and the learning process of students. The results of student learning process are contextual to the form of evidence evaluation assessment of student 
learning activities during the class. Meanwhile, according to Mudjiman (2007: 43), says that the learning activities will always be preceded by a process of making decisions to do or not do, if the motivation is strong enough then he will decide to conduct all process of learning activities.

Researchers observed while doing PPL SMKN 9 Garut with membership packages Building Design Technique study results were still dominated by the role of the teacher. As a result, the classroom atmosphere becomes monotonous, passive, and so boring. Seen a low level of understanding students' learning outcomes also result in lower. Researchers observed a lack of understanding of students on the subjects of vocational competence. Observations occurred while learning material on reinforced concrete columns in Class $\mathrm{X}$ with the number of 23 students, the overall value of the daily tests and assignments, only $35 \%$ of students graduating $\mathrm{KKM}$ and $65 \%$ of students graduating under of $\mathrm{KKM}$ (standard of mark to can be passing the lesson).

Discussion of the theories of matter needs to be understood correctly by students, thus practices depiction supported and ultimately support the learning outcomes and learning motivation. Based on the above conditions, a solution which researchers give is through the application of learning models scaffolding. Scaffolding Learning Model is a technique to support learning process during the early stages of learning then reduce aid to provide students the opportunity to take over responsibility once capable of independent learning (Katminingsih, (2009: 98)).

Based on the background and formulation problems above, the purpose of this study is: (1) To find out whether there are differences between the results of study subjects Vocational Competency with materials describing reinforced concrete beam through the students whose learning applying the learning model scaffolding with students whose learning without applying the learning model scaffolding (conventional) in the classroom X Building Design Technique SMKN 9 Garut and (2) To determine whether there is a difference between learning motivation subjects Vocational Competency in class X Building Design Technique SMKN 9 Garut.

\section{Research Methods}

The method used in this research is true experimental method includes quantitative research with this type of research posttest only control group that uses the experimental group and the control group. The research subject is class X TGB 1 SMKN 9 Garut with the number of 20 students as an experimental group and a class X TGB 2 SMKN 9 Garut with the number of 20 students as a control group. During the study researchers collaborate with the main teacher's subjects that are more experienced.

\section{Result and Discussion}

Based on the research results, there is a difference between learning outcomes of students whose learn-ing applying the learning model scaffolding with students whose learning without applying the learning model scaffolding (conventional) and there is a difference between student's motivation is learning to apply learning models scaffolding with students whose learning without applying the learning model scaffolding (conventional) in Subjects Describe Reinforced Concrete Beams. The following discussion of differences in results and motivation to learn both groups of students as well as the results of hypothesis testing and learning motivation of learning outcomes that can be described from the research.

Before discussing the differences in the results and motivation to learn both study groups specifically for the experimental group implemented first stage of the test ZPD. The test results conducted classification next ZPD between student groups ZPD A (value $>75$, KKM) with ZPD group B (value $<75$, KKM). The following pie chart test results ZPD experimental group students. 


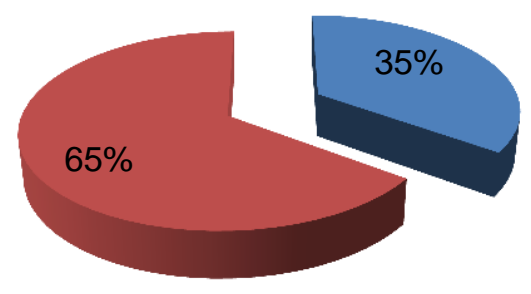
- The Group A, GRADUATED KKM $35 \%$
- The Group B, NOT GRADUATED KKM $65 \%$

Figure 1. Percentage Distribution Circle ZPD in the Value Data Test KKM Group Experiments Source: Personal Documentation

\subsection{Comparison Data Posttest and Questionnaire Experiment Group and Control}

Summary comparison of data and questionnaire posttest experimental and control groups in the materials describing reinforced concrete beams class X SMK Negeri 9 Garut shown in Table 1.

Table 1. Summary of Data Comparison posttest and Questionnaire Experiment Group and Control

\begin{tabular}{|l|l|l|l|l|}
\hline \multirow{2}{*}{ Data } & \multicolumn{2}{c|}{$\begin{array}{c}\text { Posttest Learning } \\
\text { Outcomes }\end{array}$} & \multicolumn{2}{c|}{$\begin{array}{c}\text { Learning Motivation } \\
\text { Questionnaire }\end{array}$} \\
\cline { 2 - 5 } & $\begin{array}{c}\text { The } \\
\text { Experiment } \\
\text { Group }\end{array}$ & $\begin{array}{c}\text { The } \\
\text { Control } \\
\text { Group }\end{array}$ & $\begin{array}{c}\text { The } \\
\text { Experiment } \\
\text { Group }\end{array}$ & $\begin{array}{c}\text { The } \\
\text { Control } \\
\text { Group }\end{array}$ \\
\hline Total Sample & 20 & 20 & 20 & 20 \\
\hline Lowest Score & 35 & 20 & 68 & 57 \\
\hline Highest Score & 95 & 95 & 111 & 105 \\
\hline Mean $(\mathrm{X})$ & 77,55 & 59,60 & 93,85 & 78,60 \\
\hline Median & 81 & 59,50 & 97,50 & 81 \\
\hline Modus & 82 & 80 & 100 & 57 \\
\hline SD & 14,402 & 24,186 & 13.625 & 14,372 \\
\hline
\end{tabular}

Source: Personal Analysis Results (Samawati Latifah; 2016)

3.2 Summary Results of t-test posttest Experiment Group and Control

Analysis of the data used to test the first hypothesis is separated variance t-test for homogeneity test data is not homogeneous states.

Table 2. Summary of Separated Variances t-Test Data Posttest Experiment Group and Control

\begin{tabular}{|c|c|c|c|c|}
\hline Data & $\mathbf{T}_{\text {test }}$ & $\mathbf{d f}$ & $\mathbf{T}_{\text {tabel }}$ & \multicolumn{1}{c|}{ Explanation } \\
\hline $\begin{array}{c}\text { Posttest } \\
\begin{array}{c}\text { Experiment Group } \\
\text { and Control }\end{array}\end{array}$ & 2,851 & 31 & 1,695 & $\begin{array}{l}\text { If } \mathrm{T}_{\text {test }}>\mathrm{T}_{\text {tabel }} \text { with } \alpha \\
1,695 \text { then } \mathrm{H}_{0} \text { rejected } \\
\text { and } \mathrm{H}_{\mathrm{a}} \text { accepted. }\end{array}$ \\
\hline
\end{tabular}

Source: Personal Analysis Results (Samawati Latifah; 2016)

3.3 Summary of Results of t-test Questionnaire Experiment Group and Control

Analysis of the data used to test the second hypothesis is different from the first hypothesis that the ttest for test of homogeneity of variance polled stated the data homogeneous.

Table 3. Summary Results polled Variances t-Test Data Questionnaire Experiment Group and Control

\begin{tabular}{|c|c|c|c|c|}
\hline Data & $\mathbf{T}_{\text {test }}$ & $\mathbf{d f}$ & $\mathbf{T}_{\text {tabel }}$ & \multicolumn{1}{|c|}{ Explanation } \\
\hline $\begin{array}{c}\text { Quistionnaire } \\
\text { Experiment Group and } \\
\text { Control }\end{array}$ & 2,851 & 38 & 1,685 & $\begin{array}{l}\text { If } \mathrm{T}_{\text {test }}>\mathrm{T}_{\text {tabel }} \text { with } \alpha \\
\text { o,05 so that } 2,851 \\
>1,685 \text { then } \mathrm{H}_{0}\end{array}$ \\
\hline
\end{tabular}




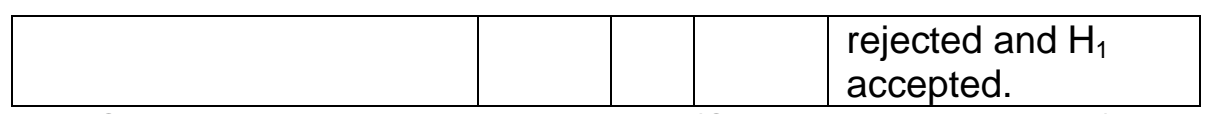

Source: Personal Analysis Results (Samawati Latifah; 2016)

From analysis above shows there is a difference between learning outcomes of students whose learning applying the learning model scaffolding with students who learning without applying the learning model scaffolding (conventional method) and there is a difference between students' motivation is learning to apply learning models scaffolding with students whose learning without applying the learning model scaffolding (conventional).
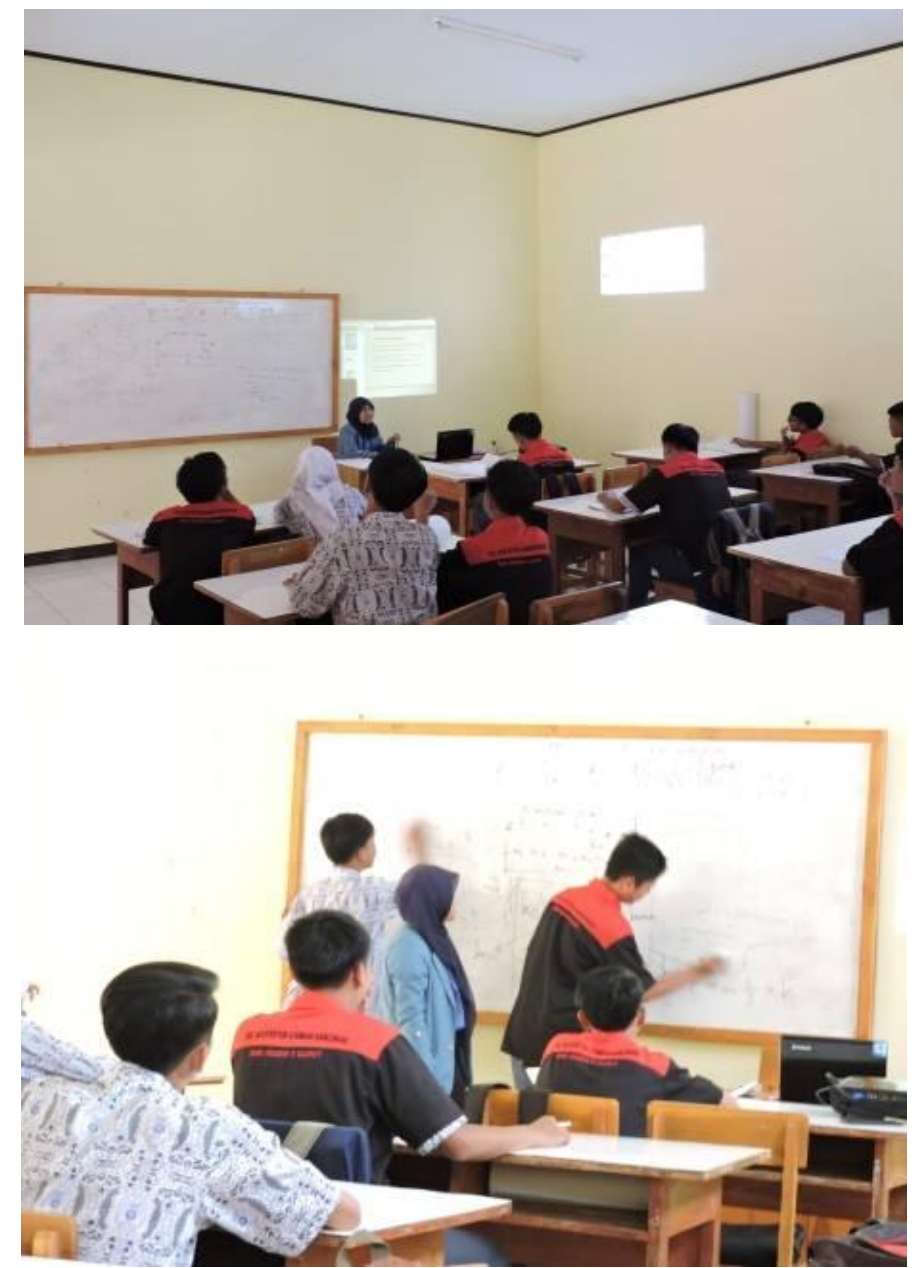

Figure 2. Application of Scaffolding model on the classroom.

Scaffolding learning outcomes learning model is superior to conventional learning models. Therefore, the implication to their motivation to learn by using scaffolding learning model is becoming superior to by conventional learning models.

\subsection{The Difference between the Results of Study Group Experiment with Control Group}

The way of treatment of the experimental group is teacher explains the material and procedures scaffolding learning model to the students. Students are grouped based on the results of tests ZPD (Zone of Proximal Development) which define the cognitive level in the classroom. Teachers help students who have difficulty learning mainly based on low ZPD group Students and teachers do the debriefing as a discussion with the help of friends. Meanwhile on the treatment of the control group, the teacher explains the material and conduct a question and answer to the students during the learning takes place. Students discuss his thoughts on the material that was submitted.

After the treatment given to both experimental and control group the next step is to conduct a posttest for both groups. The results of the experimental study group had an average score of final test (posttest) of 77.55. The control group had an average score of final test (posttest) 59.60. Posttest data processing results calculated with the help of Microsoft Excel 2010 with T-test result statistical value (Thitung), 
amounted to 2,851 with $\mathrm{df}=31$, so the value of 1.695 Ttabel (distribution of critical value) on error level of 0.05 (5\%). The calculations show a significant difference between the experimental and control groups for grades Thitung > Ttabel. Differences in study results also demonstrated through the learning process more effective experimental group compared with the control group. For the application of learning models scaffolding that can help trouble students are more focused.

\section{Conclusion}

Based on this research, it is known that there are differences in learning outcomes subjects Vocational Competency with materials describing reinforced concrete beams between students whose learning applying the learning model scaffolding with students whose learning without applying the learning model scaffolding (conventional) in class X Building Design Technique SMKN 9 Garut, Scaffolding learning outcomes learning model is superior to conventional learning models.

There are differences in motivation to study subjects difference "Vocational Competency" with materials describing reinforced concrete beams between students whose learning applying the learning model scaffolding with students who learning without applying the learning model scaffolding (conventional) in class X Building Design Technique SMKN 9 Garut. Therefore, the implication to their motivation to learn by using scaffolding learning model is becoming superior to by conventional learning models.

\section{References}

Anni, C. 2006. Psikologi belajar. Semarang: Universitas Negeri Semarang Press.

Arikunto, Suharsimi. 2010. Prosedur penelitian (suatu pendekatan praktik). Jakarta: Rineka Cipta.

Hamzah, B.U. 2006. Teori motivasi dan pengukurannya analisis di bidang pendidikan. Jakarta: Bumi Aksara.

Katminingsih, Y. 2009. Vygotsky dan teorinya dalam mempengaruhi desain pembelajaran matematika. cakrawala pendidikan Vol. 11 Nomor 1 April ISSN 1410-9883. [Online]. Diakses di http://digilib.stkippgriblitar.ac.id/24/1/Jurnal_Cakrawala_Yunl_Vygotsky.pdf

Mudjiman, H. 2007. Belajar mandiri (selfmotovated learning). Surakarta: Lembaga Pengembangan Pendidikan (LPP) \& UPT Penerbitan dan Percetakan UNS (UNS Press).

Santrock, Jhon W. 2009. Psikologi pendidikan educational psycology edisi ke 3 buku 1. Jakarta: Salemba Humanika.

Sardiman. A,M. 2009. Interaksi dan motivasi belajar mengajar. Jakarta: Radjagrafindo Persada.

Syah, M. 2004. Psikologi pendidikan dengan pendekatan baru. Bandung: Remaja Rosdakarya.

Stuyf, Rachel van der. 2002. Scaffolding as a teaching strategy. Adolescent Learning and Development Section 0500A - Fall, 17 November. [Online]. Diakses dari http://workplacesafety.pbworks.com/f/scaffold\% 20Learning.doc

Sugiyono. 2015. Metode penelitian tindakan komprehensif. Bandung: Alfabeta. 